\title{
Bio-fuels? - Across financial tsunami of 2008
}

\author{
Chia-Hsing Huang ${ }^{1}$, Liang-Chun $\mathrm{Ho}^{2 \star}$ and Shu-Shian $\mathrm{Lin}^{3}$ \\ ${ }^{1}$ SolBridge International School of Business, 151-13 Samsung 1-Dong, Dong-gu, Daejeon 300-814, South Korea. \\ ${ }^{2}$ Department of Finance, Hsiuping University of Science and Technology, 11 Gongye Rd, Dali Dist., Taichung City, \\ Taiwan. \\ ${ }^{3}$ Department of Business Administration, Chinese Culture University, Taipei City, Taiwan
}

Accepted 11 January, 2012

\begin{abstract}
The relation between prices of crude oil and grain futures was explored in this research to identify the argument about production of bio-fuels and skyrocketing grains prices. Chow breakpoint test and Quandt-Andrews unknown breakpoint test were used to examine whether the financial tsunami of 2008 resulted in any structural changes. July 15, 2008 was the breakpoint and the duration was divided into two parts. Paired variables were tested by VECM between oil and grain futures prices. The testing results of the duration from January 1, 1991 to July 14, 2008 were significant and a relationship between oil and grain prices existed indeed approving the aspect that bio-fuels cause the rising grain prices. However, the testing results after the structural changes during the financial tsunami in 2008 were insignificant completely denying the viewpoint that bio-fuels cause the rocketing grain prices.
\end{abstract}

Key words: Bio-fuel, breakpoint, financial tsunami, grain future, oil future.

\section{INTRODUCTION}

Skyrocketing prices of crops from Africa to Asia have resulted in continuous demonstrations and tumults for the past few years such as the events occurred in Egypt, Ivory Coast and Cameroon from 2007 to 2008 and Mozambique and Serbia in 2010.

Yi-fu Lin (Justin Lin), the Chief Economist and Senior Vice President for Development Economics at the World Bank, indicated that in addition to an increasing population, the demand for bio-fuels was a great challenge to the requirement for an increase in foodstuffs in the International Conference on Rural Finance in China held on September 14, 2010. The development of biofuels leading to grain price spikes was greatly condemned in the Committee on World Food Security held by Food and Agriculture Organization of the United Nations in Rome on June 3, 2008. However, the major bio-fuel producers like America, Brazil and European Union had a different view. Ed Schafer, Secretary of the United States Department of Agriculture, claimed biofuels only accounted for $2-3 \%$ and were not one of the main reasons that caused rising foodstuff prices. Tony

*Corresponding author: konah@mail.hust.edu.tw.
Burke, Australian Minister for Agriculture, Fisheries and Forestry, indicated in the Conference on Agriculture and Climate Change held in Australia on September 3, 2008 that stoppage of research and development (R and $D)$ and production of bio-fuels could not solve the global problem of food shortage.

The reasons why bio-fuels are emphasized are because they are the most suitable for vehicles of jet engines among a variety of alternative energy sources in addition to oil price spikes. To reduce the dependence on oil and decrease the impact imposed by rocketing oil prices, major industrial countries in Europe and America spare no efforts to develop and produce bio-fuels. Nevertheless, international organizations like IMF, World Bank and Food and Agriculture Organization of the United Nations consider the ingredients to make bio-fuels such as corn, soybean and wheat should be mainly used for food provisions. An increase of producing bio-fuels not only reduces food security, but also forces grain prices to keep rising.

Elobeid et al. (2007) indicated rising oil prices imposed significant impact on the output of ethanol produced by corn. Runge et al. (2007) considered to thank to high oil prices and hefty subsidies, corn-based ethanol is now all the rage in the United States. But it takes so much supply 


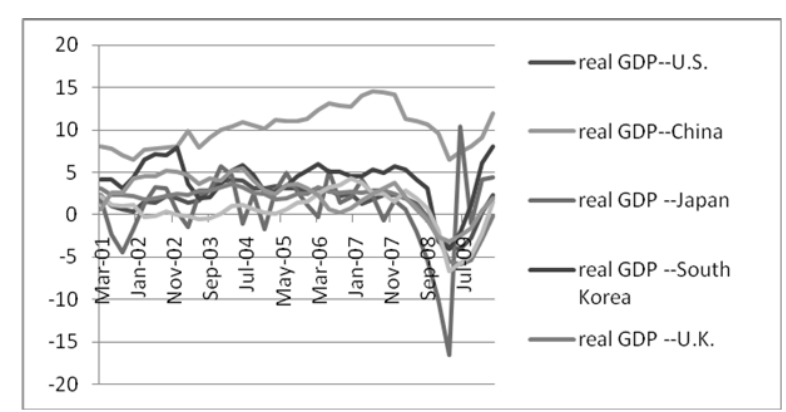

Figure 1. Real GDP growth rate. Source of data: TEJ.

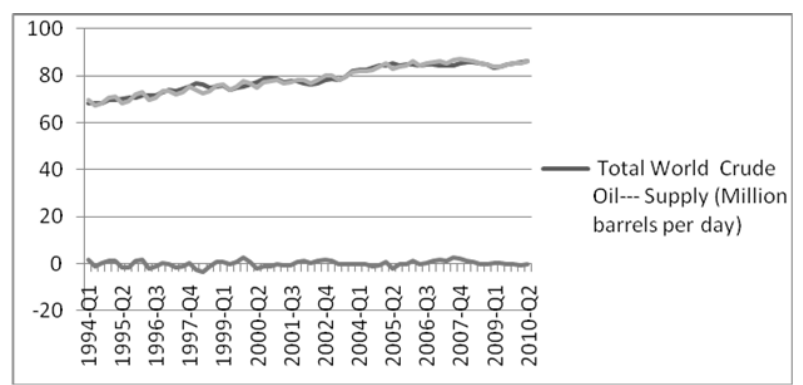

Figure 2. Total world crude oil supply and consumption and inventory. Source of data: EIA.

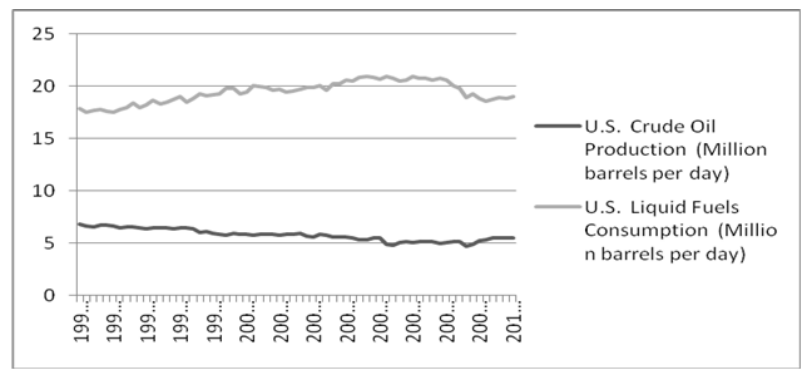

Figure 3. U.S. crude oil production and U.S. liquid fuels consumption. Source of data: EIA.

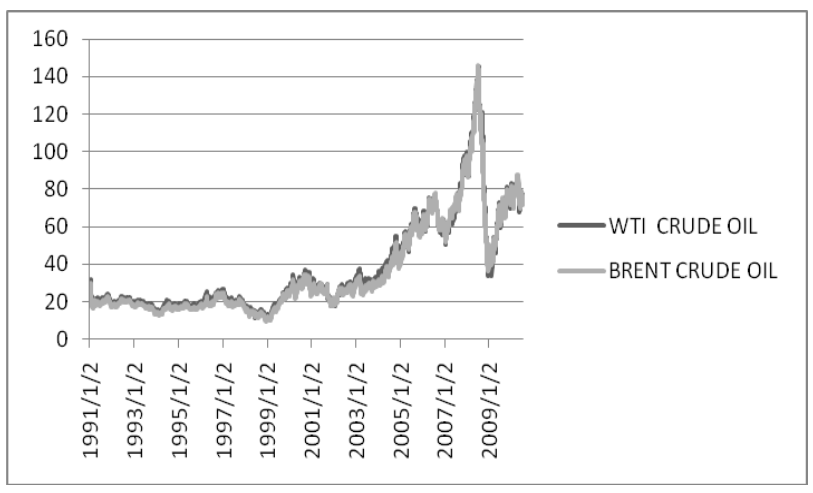

Figure 4. Supply and consumption of biodiesel and consumption of biomass in America. Source of data: EIA.

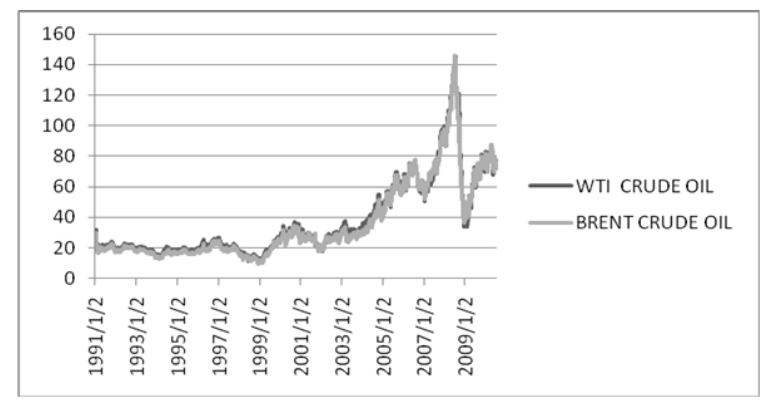

Figure 5. Chart of crude oil futures prices from 1991 to 2010. Source of data: Data Stream.

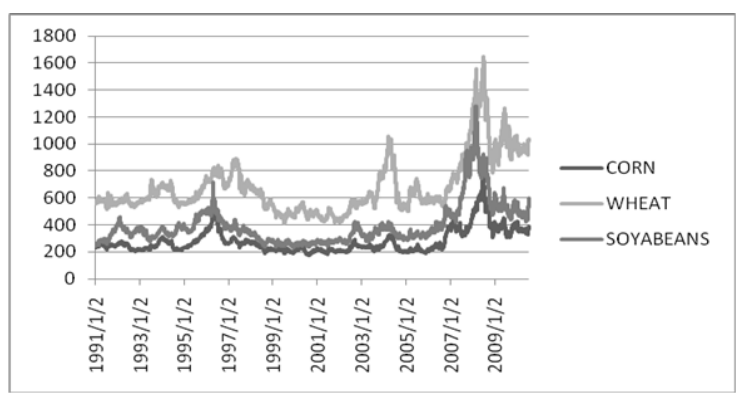

Figure 6. Chart of grain futures prices from 1991 to 2010. Source of data: Data Stream.

to keep ethanol production going that the price of corn and those of other food staples is shooting up around the world. To stop this trend, and prevent even more people from going hungry, Washington must conserve more and diversify ethanol's production inputs. Chen et al. (2010) used weekly data of crude oil, soybean, corn and wheat futures to explore the bio-fuel policy and found the biofuel policy might cause rising grain prices.

Do bio-fuels really lead to rocketing food prices and famines? Or, are bio-fuels worthy of $R$ and $D$ and production because they are only a minor factor in grain prices and famines? The arguments between supporters and opposers concerning development and production of bio-fuels are incessant. Elobeid et al. (2007) and Runge et al. (2007) indicated in their research in 2007 that oil prices affected production and prices of corn in America and the world. However, is there a relationship between oil and grain prices due to production of bio-fuels? If there is, is it a one-way or two-way relation? This is the exact topic of this research. The financial tsunami of 2008 swept over the world causing the growth rate of substantial GDP in each country to reduce significantly (Figure 1) and provision and consumption of crude oil decreased as well (Figure 2). Take the United States as an example. Production of crude oil and consumption of liquid fuels decreased (Figure 3.). Supply and demand of biodiesel reduced and consumption of biomass decreased as well (Figure 4.). Nevertheless, fluctuations of crude oil and grain futures prices were different after a dramatic drop (Figures 5 and 6.). Thus, whether the 
Table 1. Descriptive Statistics -- from January 1, 1991 to July 15, 2010.

\begin{tabular}{lccccc}
\hline Variable & WTI crude oil & BRENT crude oil & Corn & Wheat & Soybean \\
\hline Mean & 37.21434 & 35.98092 & 278.1608 & 393.3475 & 680.3424 \\
Median & 26.26000 & 24.83000 & 246.7500 & 352.2500 & 603.5000 \\
Maximum & 145.2900 & 146.0800 & 761.0000 & 1282.500 & 1649.000 \\
Minimum & 10.72000 & 9.640000 & 174.7500 & 230.7500 & 410.0000 \\
Standard development & 25.39496 & 25.67538 & 88.77291 & 149.3406 & 210.7240 \\
Skewness & 1.520584 & 1.505871 & 1.979011 & 2.198241 & 1.631951 \\
Kurtosis & 4.948803 & 4.837438 & 7.711051 & 8.742230 & 5.802636 \\
Jarque-Bera & 2662.036 & 2539.660 & 7725.006 & 10671.84 & 3776.368 \\
Probability & $(0.000000)$ & $(0.000000)$ & $(0.000000)$ & $(0.000000)$ & $(0.000000)$ \\
Observations & 4897 & 4897 & 4897 & 4897 & 4897 \\
\hline
\end{tabular}

\section{VITREQ BENTCREO}

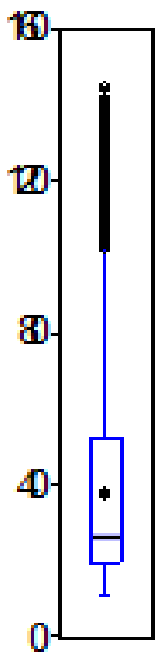

VEEAT

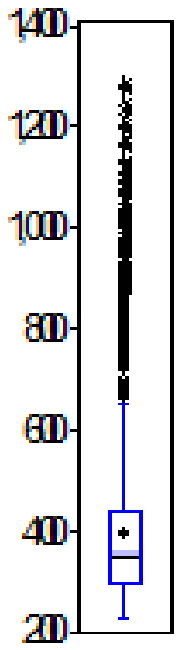

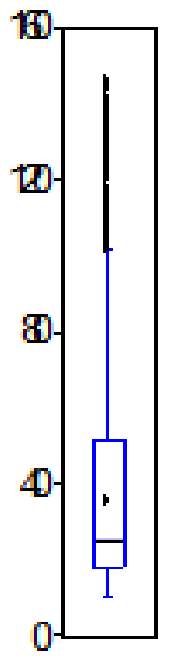

SOAEANS

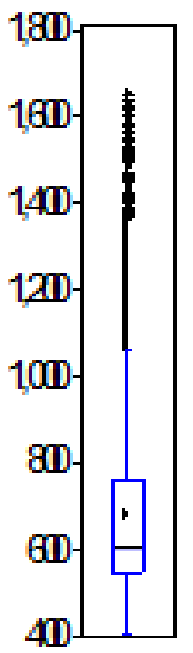

financial tsunami of 2008 resulting in structural changes is to be examined in this study first and the relationship between oil and grain prices will be investigated.

\section{RESEARCH METHODOLOGY}

Data

Currently, grains related to production of bio-fuels include corn, soybean and wheat and price discovery is a feature of futures. Thus, the daily closing prices for NYM WTI crude oil futures, ICE Brent crude oil futures and CBOT corn, wheat and soybean futures were adopted in this research. The duration began on January 1 , 1991 and ended on July 15, 2010. There are 4,897 samples after excluding non transaction days and the source of data is from Data Stream.

Table 1 is the descriptive statistics of the samples under study. The medians of WTI crude oil, Brent crude oil, corn, wheat and soybean are all smaller than the means and skewness is positive causing slanting rightward. Kurtosis values of all variables are bigger than 3 revealing a peak heavy-tailed distribution (leptokurtosis). Besides, Jarque-Bera values of all variables are very large with a Probability of 0 rejecting the null hypothesis $\left(\mathrm{H}_{0}\right.$ : a normal distribution for samples).

The 25th percentiles, medians and the 75th percentiles of all variables are shown in the box plot in Figure 7 . The means $(\bullet)$ of variables are bigger than medians as the values shown in Table 1 and the upper whiskers of all variables are longer than the lower whiskers in the box plot.

Figure 8 indicates the variables of this research are disobedient to a normal distribution since the Quantile- Quantile plot (Q-Q plot) was mapped by the means and variances of data under a normal distribution and compared with the actual data. If they comply with a normal distribution, then the two lines in the plot will be overlapped to become one; however, the two lines in the $Q-Q$ plot did not overlap in Figure 8.

\section{Structural changes}

As the study period began on January 1, 1991 and ended on July 15,2010 crossing over the financial tsunami in 2008, structural changes might occur. Consequently, Chow Breakpoint Test and Quandt-Andrews unknown breakpoint test were used to examine if any structural changes occurred during this study period. $5 \%$ in the null hypothesis ( $\mathrm{HO}$ : No breakpoints within 5\% trimmed) was proposed by Hansen (2001). 
WTI CRUDE OIL

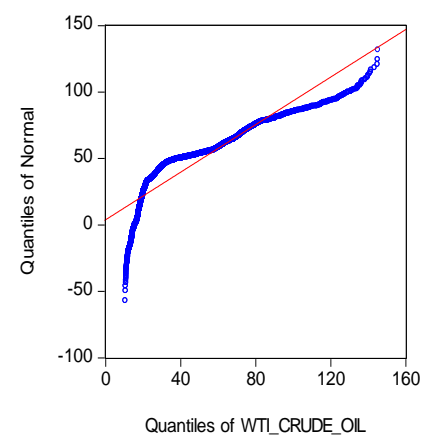

CORN

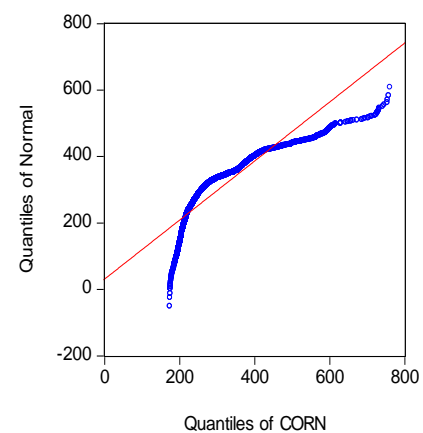

SOYABEANS

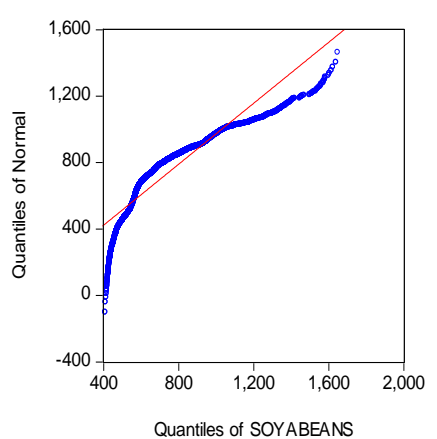

Figure 8. Quantile-Quantile plot from January 1, 1991 to July 15, 2010.

\section{Unit root test and co-integration test}

The null hypothesis $(\mathrm{HO})$ was tested by the ADF (Augmented Dickey-Fuller) testing method as $\mathrm{HO}$ can't be rejected easily when the data are very close to unit roots and ADF testing is conducted (Sims, 1988). Moreover, PP (Phillips-Perron) testing was also applied for reinforcement.

Co-integration testing refers to test if the linear combination of a group of non-stationary time series variables becomes stationary. In other words, a co-integration test is conducted to discover whether a long-term equilibrium exists among variables. Johansen's cointegration test (Johansen, 1991, 1992; Johansen et al., 1990) was adopted in this research since a number of variables can be processed at the same time and the number of co-integration vectors can be tested by trace and Max-Eigen. A greater number of co-integration vectors represent a more steady long-term equilibrium (Hammoudeh et al., 2004).
Vector error correction model (VECM)

The VAR model proposed by Sims (1980) can be written as follows:

$$
\mathbf{X}_{t}=\mathbf{K}+\mathbf{A}_{1} \mathbf{X}_{-1}+\ldots+\mathbf{A}_{p} \mathbf{X}_{-p}+\mathbf{B} \mathbf{Y}_{t}+\mathbf{e}_{t}
$$

Where $K$ is a $(n \times 1)$ vector of intercept terms, $X_{t}$ is a $(n \times 1)$ vector of endogenous variables, $Y_{t}$ is a $(n \times 1)$ vector of exogenous variables, $A$ and $B$ are $(n \times n)$ matrix of coefficients, $p$ is the number of lags, et is a $(n \times 1)$ vector of error terms for $t=1,2, \ldots . T$.

A VECM is a restricted VAR model. The VECM specification restricts the long run behavior of the endogenous variables to converge to their long run equilibrium relationships and allow the short run dynamics. The VECM proposed by Johansen (1988) can be written as follows:

$$
\begin{aligned}
& \Delta \mathbf{X}_{t}=\mathbf{K}+\boldsymbol{\Pi} \mathbf{X}_{t-1}+\boldsymbol{\Gamma}_{1} \Delta \mathbf{X}_{t-2}+\cdots+\boldsymbol{\Gamma}_{p-1} \Delta \mathbf{X}_{t-p+1}+\mathbf{B} \mathbf{Y}_{t}+\mathbf{e}_{t} \\
& \boldsymbol{\Pi}=\sum_{i=1}^{p} \mathbf{A}_{j}-\mathbf{I} \quad \boldsymbol{\Gamma}_{i}=-\sum_{j=i+1}^{p} \mathbf{A}_{j}
\end{aligned}
$$

Where $P$ : the number of lags.

The vector error correction model was used in this research to test short-term interaction among the variables as the VECM is more appropriate than the VAR model for prediction when cointegration exists among variables (Granger et al., 1988). Balcombe et al. (2008) took the prices of sugar, crude oil and ethanol in Brazil as variables and selected the most suitable model by the Bayesian ratio to investigate influence among these variables. They found the linear VECM could interpret the interaction between sugar and crude oil prices better though a nonlinear asymmetric relationship existed.

Paired variables including corn vs. WTI crude oil, wheat vs. WTI crude oil, soybean vs. WTI crude oil, corn vs. Brent crude oil, wheat vs. Brent crude oil and soybean vs. Brent crude oil were tested for Granger causality and impulse responses.

If the testing results of Granger causality and impulse responses are significant, relations among these variables exist indeed and the viewpoint that production of bio-fuels leads to rising grain prices is confirmed. The agency in charge needs to deliberate on policymaking of bio-fuels in many ways.

Rising oil prices $\rightarrow$ Production of bio-fuels $\rightarrow$ Food provision crowded out $\rightarrow$ Rising grain prices

On the contrary, no relations exist among variables. Therefore, when the testing results are insignificant, the aspect that production of bio-fuels edges out food supply and further leads to rising grain prices is overruled.

Rising oil prices $\rightarrow$ Production of bio-fuels? Food provision crowded out? Rising grain prices

\section{EMPIRICAL RESULTS}

\section{Structural changes}

As the oil price fluctuations are focused in this research, structural changes are tested by WTI crude oil and Brent crude oil prices. According to Tables 2 and 3 and Figures 9 and 10, a breakpoint occurred between July 7, 2008 
Table 2. Quandt-Andrews unknown breakpoint test.

\begin{tabular}{llcc}
\hline Variable & Breakpoint & Value & Probability \\
\hline \multirow{2}{*}{ WTI crude oil } & Maximum LR F-statistic ---07/15/2008 & 31.60562 & 0.0000 \\
& Maximum Wald F-statistic --- 07/15/2008 & 31.60562 & 0.0000 \\
& & & \\
\multirow{2}{*}{ BRENT crude oil } & Maximum LR F-statistic ---07/07/2008 & 38.49924 & 0.0000 \\
& Maximum Wald F-statistic ---07/07/2008 & 38.49924 & 0.0000 \\
\hline
\end{tabular}

Null hypothesis denotes no breakpoints within 5\% trimmed (Hansen, 1997, 2001).

Table 3.Chow breakpoint test.

\begin{tabular}{lcccc}
\hline Variable & Breakpoint & $\begin{array}{c}\text { F-statistic } \\
\text { [Probability (1,4894)] }\end{array}$ & $\begin{array}{c}\text { Log likelihood ratio } \\
\text { (Probability Chi-Square(1)) }\end{array}$ & $\begin{array}{c}\text { Wald Statistic } \\
\text { (Probability Chi-Square(1)) }\end{array}$ \\
\hline \multirow{2}{*}{ WTI crude oil } & $07 / 07 / 2008$ & $31.20256(0.0000)$ & $31.11623(0.0000)$ & $31.20256(0.0000)$ \\
& $07 / 15 / 2008$ & $31.60562(0.0000)$ & $31.51688(0.0000)$ & $31.60562(0.0000)$ \\
\multirow{2}{*}{ BRENT crude oil } & $07 / 07 / 2008$ & $38.49924(0.0000)$ & $38.36427(0.0000)$ & $38.49924(0.0000)$ \\
& $07 / 15 / 2008$ & $36.33034(0.0000)$ & $36.21095(0.0000)$ & $36.33034(0.0000)$ \\
\hline
\end{tabular}

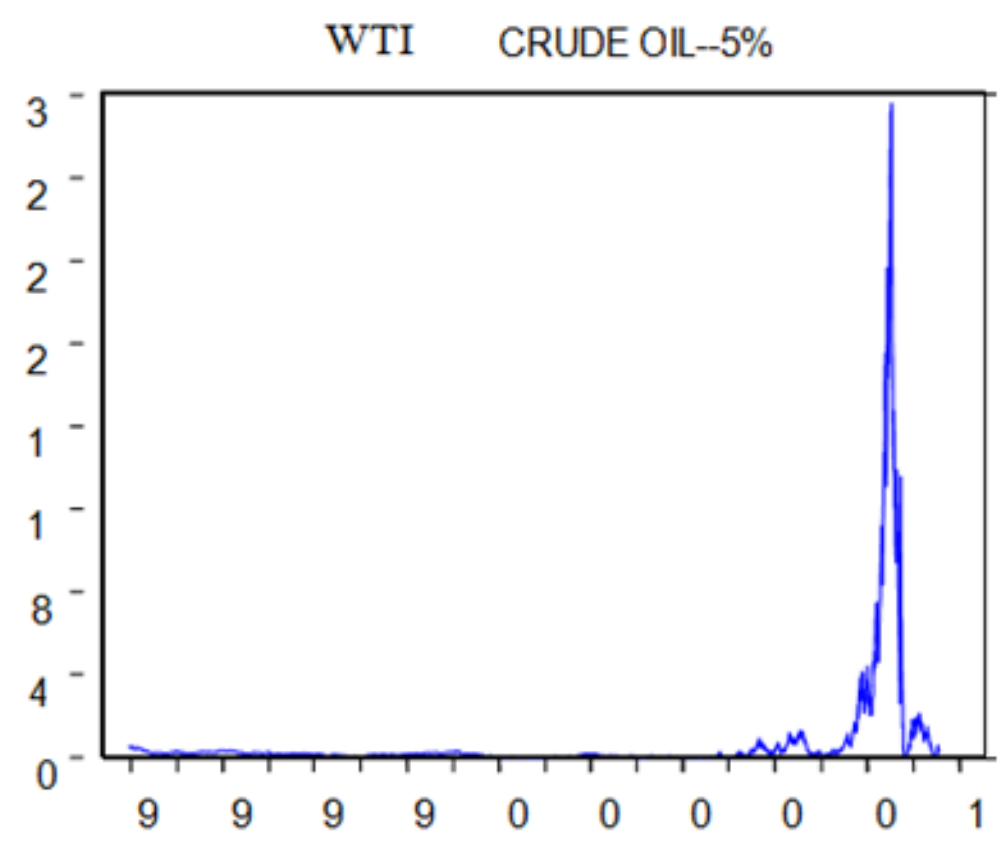

Figure 9. Quandt-Andrews unknown breakpoint test-5\% trimmed.

and July 15, 2008 by conducting Chow Breakpoint Test and Quandt - Andrews's unknown breakpoint test. It is thus known that the financial tsunami of 2008 caused structural changes. Furthermore, as the closing prices of WTI crude oil and BRENT crude oil on July 14, 2008 were unprecedented high, July 15, 2008 was used as the breakpoint in this research. Thus, the research duration is divided into two sections, from January 1, 1991 to July
14, 2008 and from July 15, 2008 to July 15, 2010.

\section{Unit root test}

According to Tables 4 and 5, the ADF and PP unit root test results of the variables before differentiating are insignificant and the null hypothesis can't be denied. After 


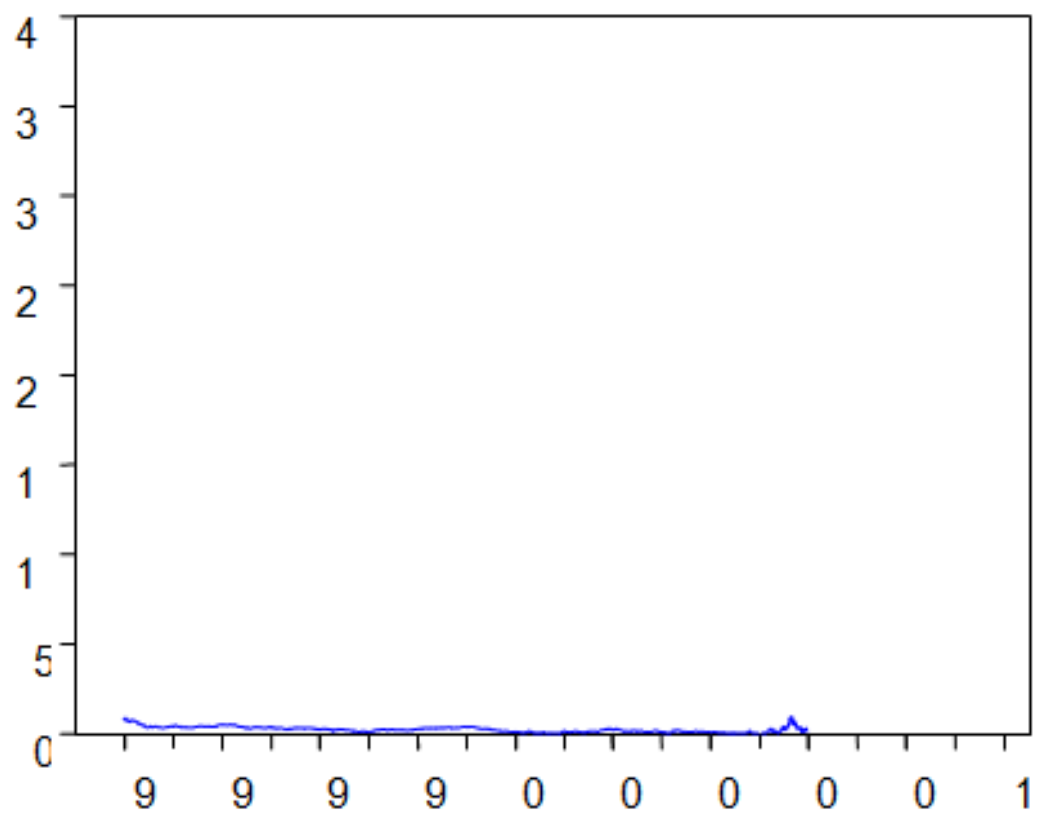

Figure 10. Quandt-Andrews unknown breakpoint test-5\% trimmed.

Table 4. Unit Root Test—from January 1, 1991 to July 14, 2008.

\begin{tabular}{|c|c|c|c|c|c|c|}
\hline Panel A: Level & & WTI crude oil & BRENT crude oil & Corn & Wheat & Soybean \\
\hline \multirow{2}{*}{ Intercept } & ADF & 1.0000 & 1.0000 & 1.0000 & 0.8313 & 0.9999 \\
\hline & $\mathrm{PP}$ & 1.0000 & 1.0000 & 1.0000 & 0.8834 & 0.9999 \\
\hline \multirow{2}{*}{ Intercept and Trend } & ADF & 1.0000 & 1.0000 & 1.0000 & 0.9103 & 1.0000 \\
\hline & $\mathrm{PP}$ & 1.0000 & 1.0000 & 1.0000 & 0.9419 & 1.0000 \\
\hline \multicolumn{7}{|c|}{ Panel B: First difference } \\
\hline \multirow{2}{*}{ Intercept } & ADF & $0.0001^{*}$ & $0.0001^{*}$ & $0.0001^{*}$ & $0.0000^{*}$ & $0.0001^{*}$ \\
\hline & PP & $0.0001^{*}$ & $0.0001^{*}$ & $0.0001^{*}$ & $0.0001^{*}$ & $0.0001^{*}$ \\
\hline \multirow{2}{*}{ Intercept and Trend } & ADF & $0.0000^{*}$ & $0.0000^{*}$ & $0.0000^{*}$ & $0.0000^{*}$ & $0.0000^{\star}$ \\
\hline & $\mathrm{PP}$ & $0.0000^{*}$ & $0.0000^{*}$ & $0.0000^{*}$ & $0.0000^{*}$ & $0.0000^{*}$ \\
\hline
\end{tabular}

ADF and PP denotes p-values, ${ }^{*}$ denotes rejection of the null hypothesis $\left(H_{0}\right)$ at the 0.01 level.

Table 5. Unit Root Test-from July 15, 2008 to July 15, 2010.

\begin{tabular}{|c|c|c|c|c|c|c|}
\hline Panel A: Level & & WTI crude oil & BRENT crude oil & Corn & Wheat & Soybean \\
\hline \multirow{2}{*}{ Intercept } & ADF & 0.0158 & $0.0058^{*}$ & $0.0000^{*}$ & 0.0426 & $0.0016^{*}$ \\
\hline & PP & 0.0115 & $0.0052^{*}$ & $0.0000^{*}$ & 0.0453 & $0.0016^{*}$ \\
\hline \multirow{2}{*}{ Intercept and Trend } & ADF & 0.1024 & 0.0474 & $0.0042^{*}$ & 0.5376 & 0.0354 \\
\hline & $\mathrm{PP}$ & 0.0705 & 0.0331 & $0.0044^{*}$ & 0.4390 & 0.0347 \\
\hline \multicolumn{7}{|c|}{ Panel B: First difference } \\
\hline \multirow{2}{*}{ Intercept } & ADF & $0.0000^{*}$ & $0.0000^{*}$ & $0.0000^{*}$ & $0.0000^{*}$ & $0.0000^{*}$ \\
\hline & $\mathrm{PP}$ & $0.0000^{*}$ & $0.0000^{*}$ & $0.0000^{*}$ & $0.0000^{*}$ & $0.0000^{*}$ \\
\hline \multirow{2}{*}{ Intercept and Trend } & ADF & $0.0000^{*}$ & $0.0000^{*}$ & $0.0000^{*}$ & $0.0000^{*}$ & $0.0000^{*}$ \\
\hline & PP & $0.0000^{*}$ & $0.0000^{*}$ & $0.0000^{*}$ & $0.0000^{*}$ & $0.0000^{*}$ \\
\hline
\end{tabular}

ADF and PP denotes p-values, ${ }^{*}$ denotes rejection of the null hypothesis $\left(\mathrm{H}_{0}\right)$ at the 0.01 level. 
Table 6. Cointegration Tests (1).

\begin{tabular}{|c|c|c|c|c|c|c|c|c|c|c|}
\hline \multirow{3}{*}{ Data trend } & \multicolumn{10}{|c|}{ WTI crude oil and corn and wheat and soybean } \\
\hline & \multicolumn{5}{|c|}{ Time: 01/01/1991-07/14/2008 } & \multicolumn{5}{|c|}{ Time: 07/15/2008-07/15/2010 } \\
\hline & None & None & Linear & Linear & Quadratic & None & None & Linear & Linear & Quadratic \\
\hline \multirow{2}{*}{ Test Type } & No intercept & Intercept & Intercept & Intercept & Intercept & No intercept & Intercept & Intercept & Intercept & Intercept \\
\hline & No trend & No trend & No trend & Trend & Trend & No trend & No trend & No trend & Trend & Trend \\
\hline Trace & 2 & 3 & 4 & 1 & 1 & 1 & 1 & 1 & 1 & 1 \\
\hline Man-Eigen & 2 & 1 & 1 & 1 & 1 & 1 & 1 & 1 & 1 & 1 \\
\hline
\end{tabular}

Selected at 0.05 level, critical values based on MacKinnon-Haug-Michelis (1999).

Table 7. Cointegration Tests (2).

\begin{tabular}{|c|c|c|c|c|c|c|c|c|c|c|}
\hline \multirow{3}{*}{ Data trend } & \multicolumn{10}{|c|}{ Brent crude oil and corn and wheat and soybean } \\
\hline & \multicolumn{5}{|c|}{ Time: 01/01/1991-07/14/2008 } & \multicolumn{5}{|c|}{ Time: 07/15/2008-07/15/2010 } \\
\hline & None & None & Linear & Linear & Quadratic & None & None & Linear & Linear & Quadratic \\
\hline Toct Tyno & No Intercept & Intercept & Intercept & Intercept & Intercept & No Intercept & Intercept & Intercept & Intercept & Intercept \\
\hline Test Iype & No Trend & No Trend & No Trend & Trend & Trend & No Trend & No Trend & No Trend & Trend & Trend \\
\hline Trace & 3 & 3 & 4 & 1 & 2 & 1 & 1 & 1 & 1 & 1 \\
\hline Man-Eig & 1 & 1 & 1 & 1 & 1 & 0 & 1 & 1 & 1 & 1 \\
\hline
\end{tabular}

Selected at 0.05 level, critical values based on MacKinnon-Haug-Michelis (1999).

Table 8. Granger causality test from January 1, 1991 to July 14, 2008.

\begin{tabular}{|c|c|c|c|c|c|c|}
\hline \multicolumn{2}{|c|}{ Dependent variable $\left(\mathrm{H}_{0:}\right.$ Excluded) } & \multirow{2}{*}{$\begin{array}{c}\text { WTI crude oil } \\
-\end{array}$} & \multirow{2}{*}{$\begin{array}{c}\text { Corn } \\
0.0000^{\star *}\end{array}$} & \multirow{2}{*}{$\begin{array}{c}\text { Wheat } \\
0.0000^{\star *}\end{array}$} & \multirow{2}{*}{$\begin{array}{l}\text { Soybean } \\
0.0000^{* *}\end{array}$} & \multirow{2}{*}{$\begin{array}{c}\text { BRENT crude oil } \\
0.0011^{\star *}\end{array}$} \\
\hline & WTI crude oil & & & & & \\
\hline & Corn & $0.0048^{* *}$ & - & 0.1083 & 0.5970 & $0.0000^{\star *}$ \\
\hline \multirow[t]{3}{*}{ Probability } & Wheat & $0.0489^{* *}$ & 0.1287 & - & $0.0021^{* *}$ & $0.0002^{* *}$ \\
\hline & Soybean & $0.0384^{* *}$ & 0.1487 & 0.0663 & - & $0.0015^{\star *}$ \\
\hline & Brent crude oil & $0.0259^{* *}$ & $0.0000^{* *}$ & $0.0000^{* *}$ & $0.0000^{* *}$ & - \\
\hline
\end{tabular}

** denotes rejection of the null hypothesis $\left(\mathrm{H}_{0}\right)$ at the 0.05 level.

first-order difference, the ADF and PP unit root test results in Tables 4 and 5 are significant at $1 \%$ significant level rejecting the null hypothesis $\left(\mathrm{H}_{0}\right)$ of unit root.

\section{Co-integration tests}

Tables 6 and 7 indicate the number of co-integration vectors of Max-Eigen is zero and that of the other traces or Max-Eigen is bigger or equivalent to 1 at $5 \%$ significant level without any intercept and trend from July 15, 2008 to July 15,2010 for variables of Brent crude oil, corn, wheat and soybean only.

In summary, the testing results show that the long-term equilibrium of variables including WTI crude oil, Brent crude oil, corn, wheat and soybean is stable.

\section{Granger causality test}

The Granger causality test may reveal if other variables are affected when changes occur among the variables; that is, the explanatory power to changes of other variables. The results of the Granger causality test are listed in Tables 8 and 9.

According to Table 8 , variables of WTI crude oil, corn, wheat and soybean interacted mutually and so did those of Brent crude oil, corn, wheat and soybean during the period from January 1, 1991 to July 14, 2008. In other words, there was an explanatory power for each other.

Nevertheless, the testing results in Table 9 are contrary to those in Table 8 since the variables of WTI crude oil, corn, wheat and soybean were insignificant and so were those of Brent crude oil, corn, wheat and soybean during 
Table 9. Granger causality test from July 15, 2008 to July 15, 2010.

\begin{tabular}{llccccc}
\hline Dependent variable $\mathrm{H}_{0}$ : Excluded & WTI crude oil & Corn & Wheat & Soybean & BRENT crude oil \\
\hline & WTI crude oil & - & 0.4644 & 0.4203 & 0.7356 & 0.0615 \\
Prob. & WORN & 0.3578 & - & 0.1919 & $0.0390^{\star *}$ & 0.3525 \\
& WHEAT & 0.1257 & 0.0648 & - & $0.0495^{\star *}$ & 0.7484 \\
& SOYABEANS & 0.5075 & $0.0160^{* *}$ & 0.5763 & - & 0.2424 \\
& BRENT crude oil & 0.3947 & 0.0886 & 0.3637 & 0.6309 & - \\
\hline
\end{tabular}

** denotes rejection of the null hypothesis $\left(\mathrm{H}_{0}\right)$ at the 0.05 level.
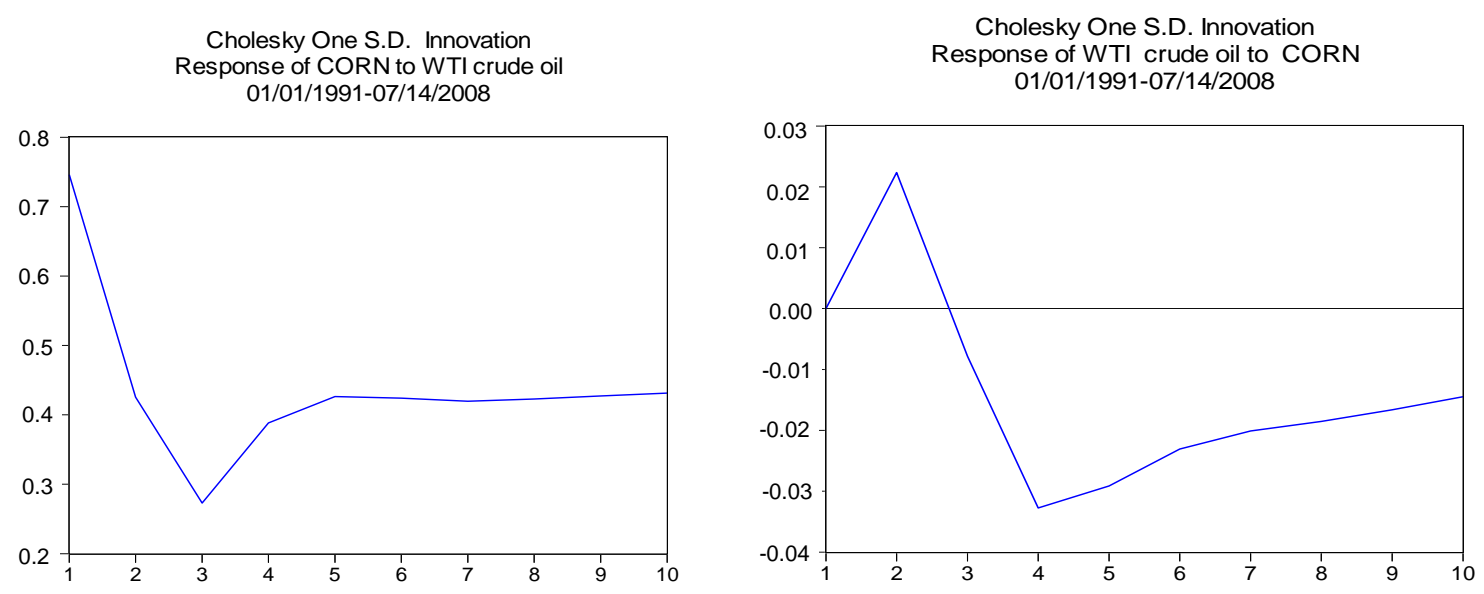

Figure 11. Responses of Corn to WTI crude oil and responses of WTI crude oil to Corn.
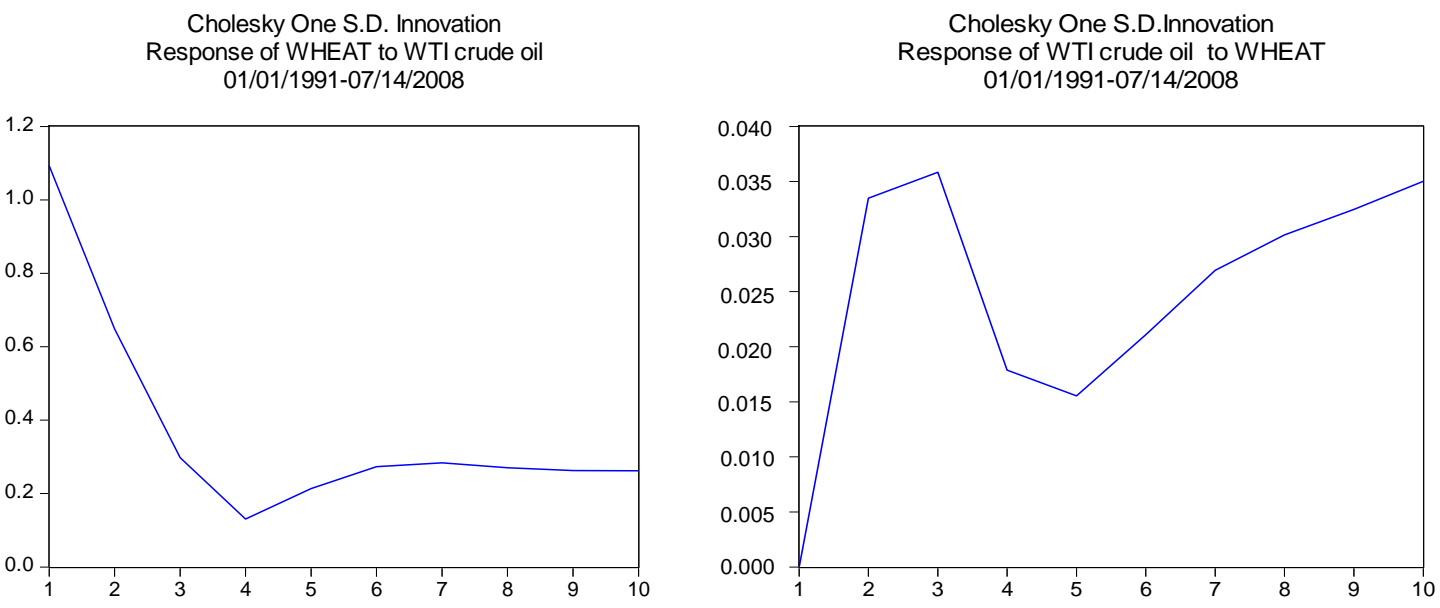

Figure 12. Responses of Wheat to WTI crude oil and responses of WTI crude oil to Wheat.

the period from July 15, 2008 to July 15, 2010.

\section{Impulse responses}

Impulse responses may indicate the dynamic responses of variables to unexpected impulses from other variables. In another word, impulse responses can observe if variables are able to respond to those unexpected impulses in a fast and effective way so that dynamic interactions among variables can be further understood. Testing results of impulse responses are arranged by periods and variables in this research and shown in Figures 11 through 22.

In Figures 11 to 16, impulse responses of WTI crude oil and Brent crude oil to corn, wheat and soybean are significant during the period from January 1, 1991 to July 

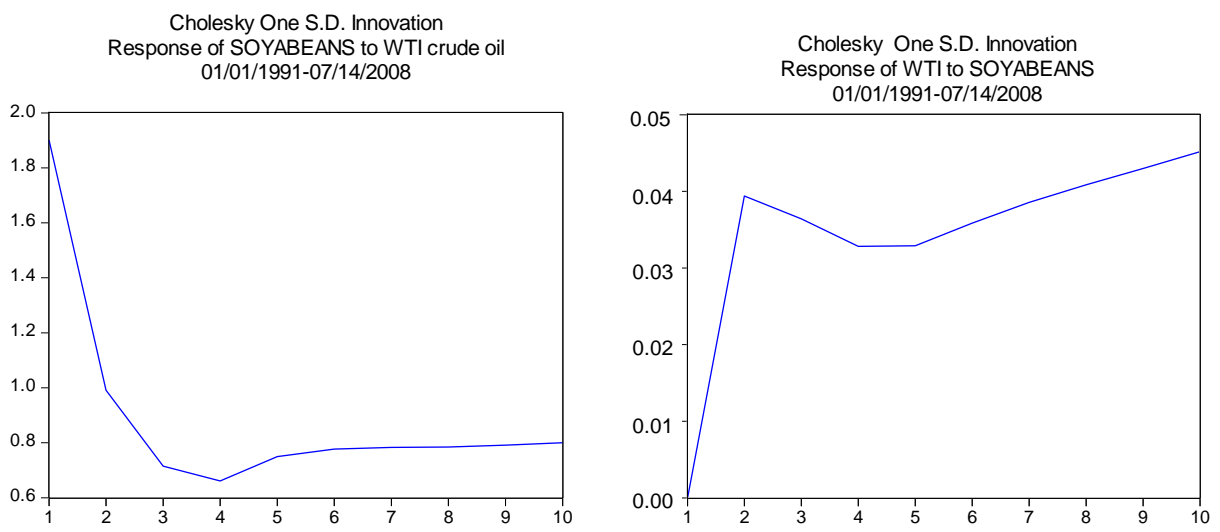

Figure 13. Responses of Soybean to WTI crude oil and responses of WTI crude oil to Soybean.
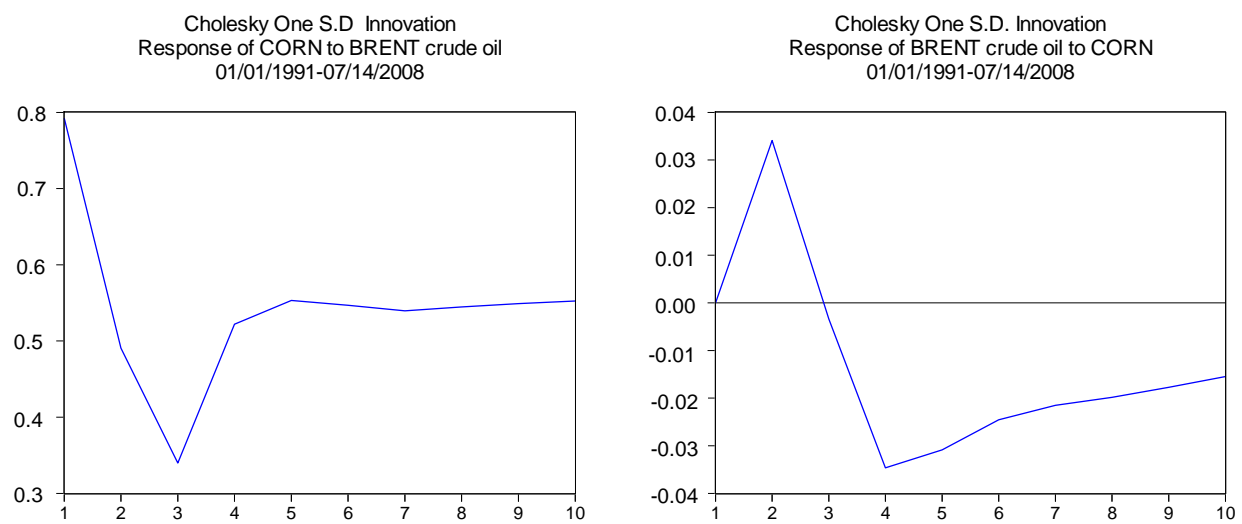

Figure 14. Responses of Corn to Brent crude oil and responses of Brent crude oil to Corn.
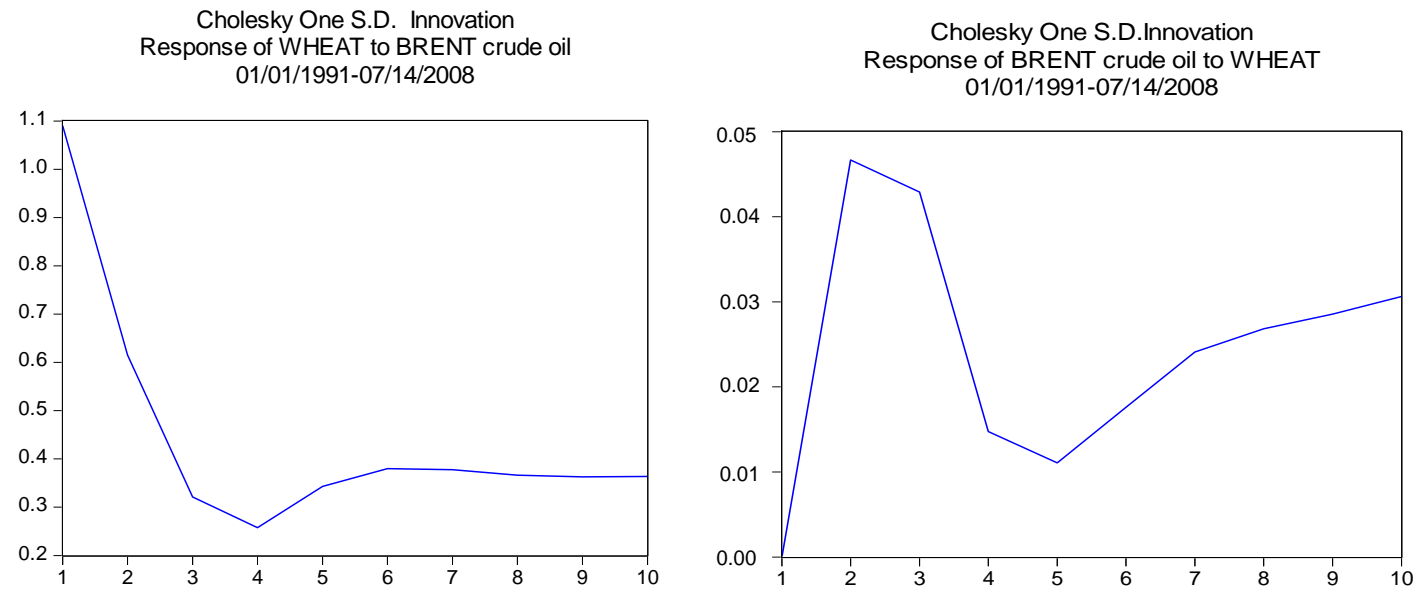

Figure 15. Responses of Wheat to Brent crude oil and responses of Brent crude oil to Wheat.

14, 2008. At first, they ascended and then descended; however, they arose by periods afterwards.
In Figures 17 to 22, either the impulse responses of corn, wheat and soybean to WTI crude oil and Brent 
Cholesky One S.D. Innovation Response of SOYABEANS to BRENT crude oil 01/01/1991-07/14/2008

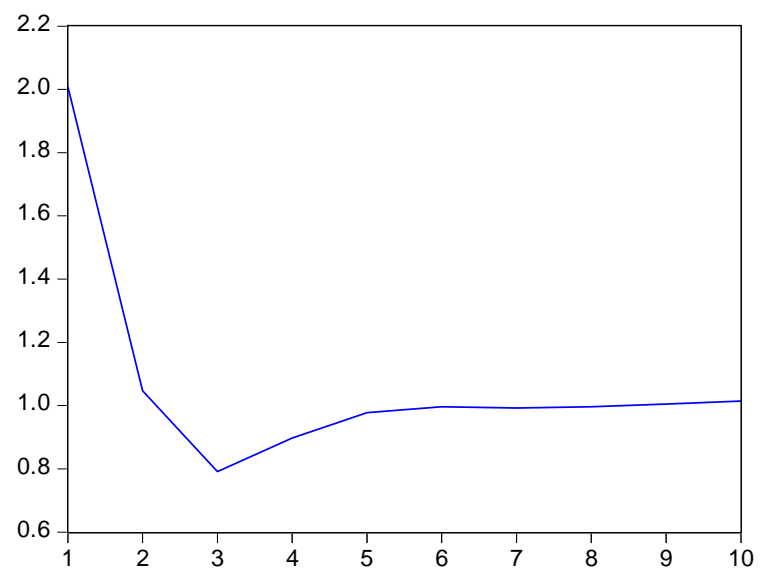

Cholesky One S.D.Innovation Response of BRENT crude oil to SOYABEANS 01/01/1991-07/14/2008

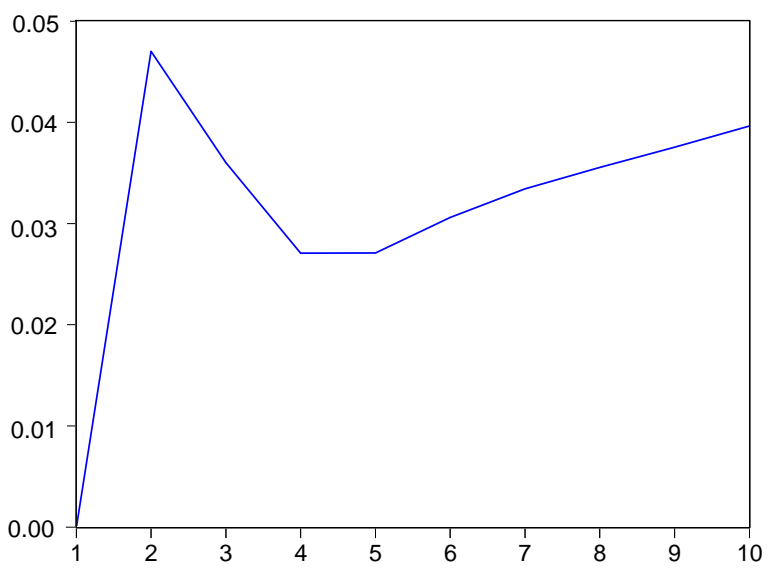

Figure 16. Responses of Soybean to Brent crude oil and responses of Brent crude oil to Soybean.

\section{Response to Cholesky One S.D. Innovations 07/15/2008-07/15/2010}

Response of CORN to WTI crude oil

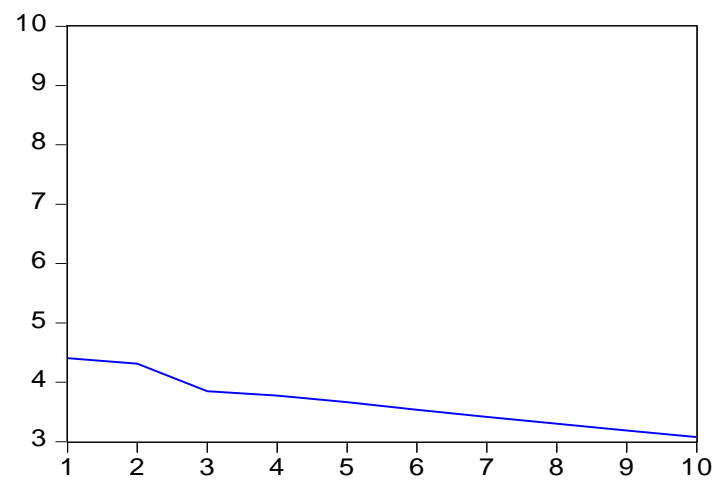

Response of WTI crude oil to CORN

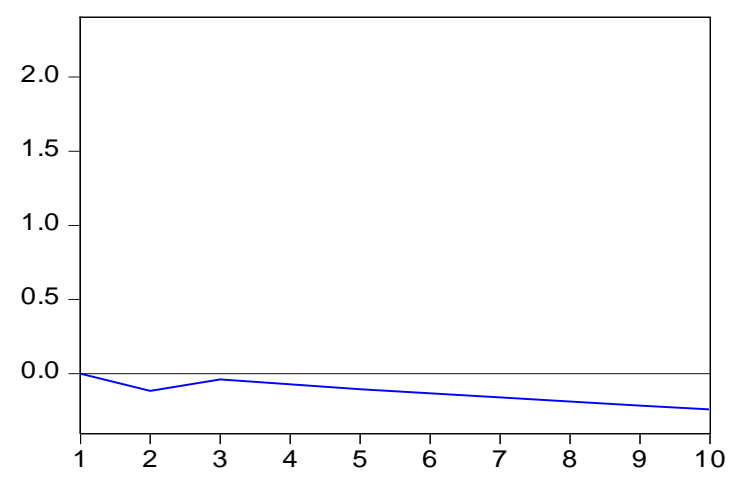

Figure 17. Responses of Corn to WTI crude oil and responses of WTI crude oil to Corn.

\section{Response to Cholesky One S.D. Innovations 07/15/2008-07/15/2010}

Response of WHEAT to WTI crude oil

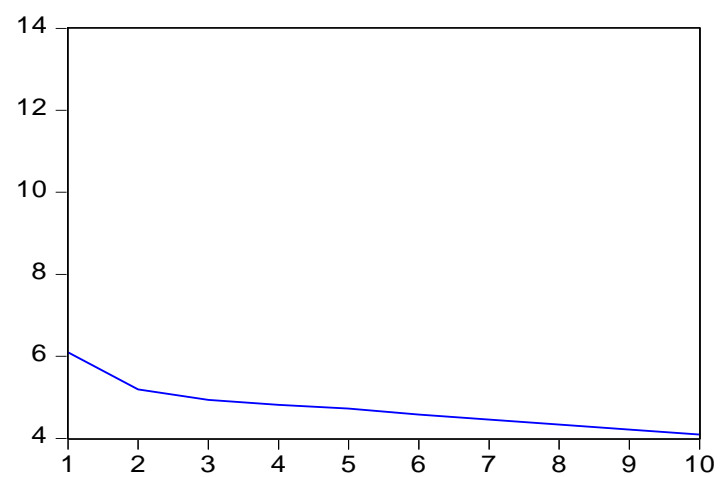

Response of WTI crude oil to WHEAT

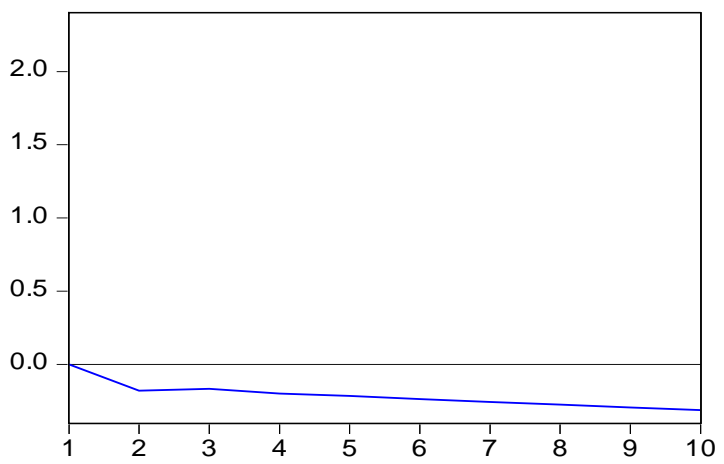

Figure 18. Responses of Wheat to WTI crude oil and responses of WTI crude oil to Wheat. 


\section{Response to Cholesky One S.D. Innovations \\ 07/15/2008-07/15-2010}

Response of SOYABEANS to WTI crude oil

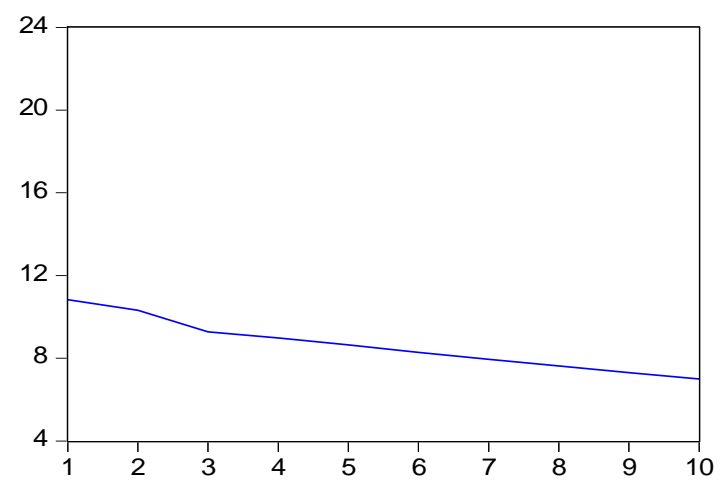

Response of WTI crude oil to SOYABEANS

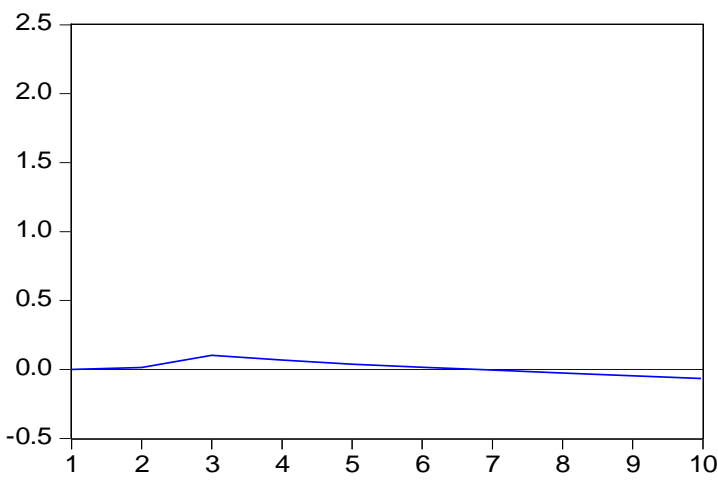

Figure 19. Responses of Soybean to WTI crude oil and responses of WTI crude oil to Soybean.

Response to Cholesky One S.D. Innovations

07/15/2008-07/15/2010

Response of CORN to BRENT crude oil

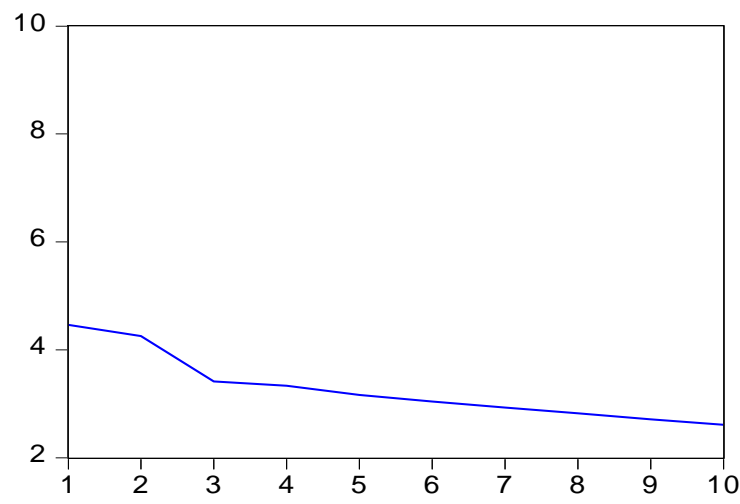

Response of BRENT crude oil to CORN

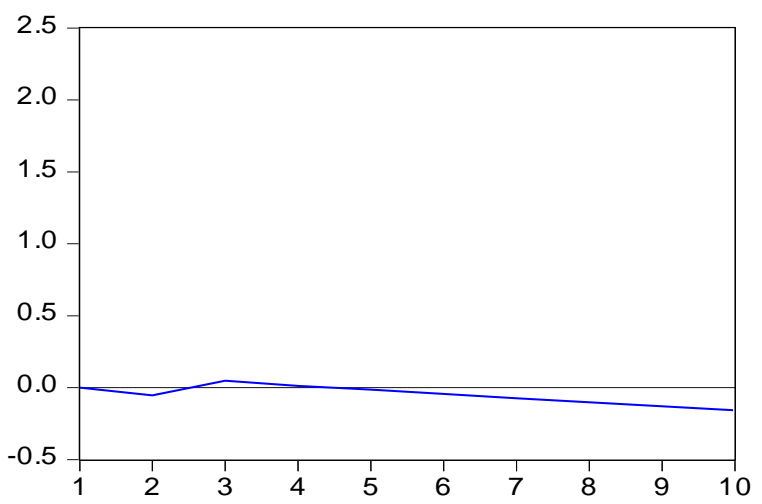

Figure 20. Responses of corn to Brent crude oil and responses of Brent crude oil to corn.

Response to Cholesky One S.D. Innovations 07/15/2008-07/15/2010

Response of WHEAT to BRENT crude oil

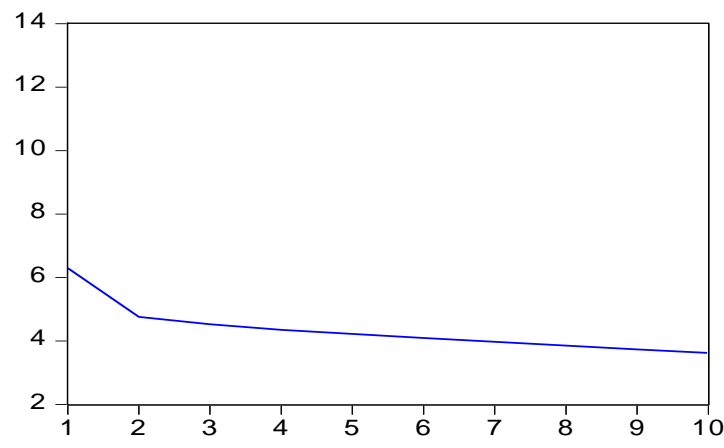

Response of BRENT crude oil to WHEAT

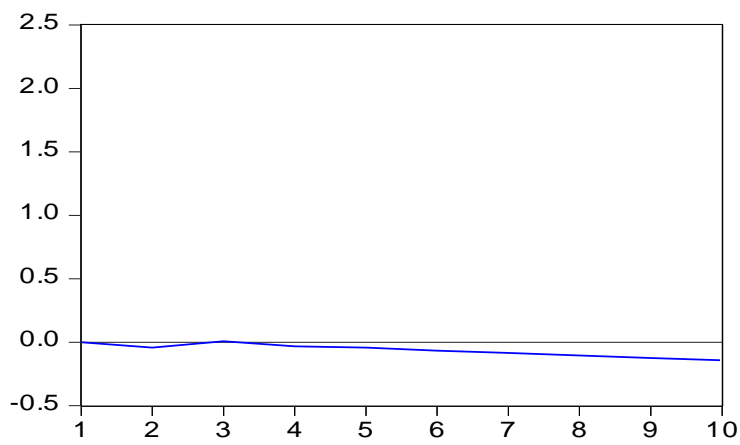

Figure 21. Responses of wheat to Brent crude oil and responses of Brent crude oil to wheat. 
Response to Cholesky One S.D. Innovations

07/15/2008-07/15/2010

Response of SOYABEANS to BRENT crude oil

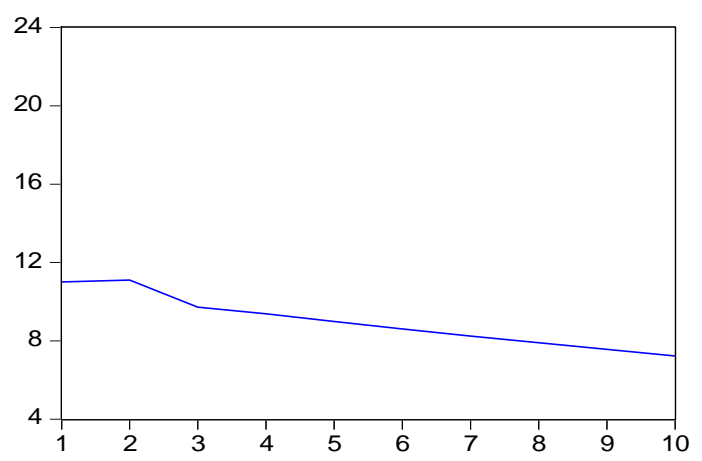

Response of BRENT crude oil to SOYABEANS

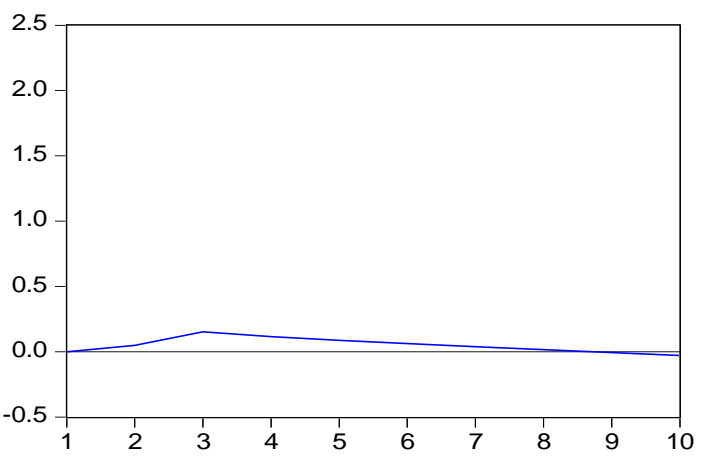

Figure 22. Responses of Soybean to Brent crude oil and responses of Brent crude oil to Soybean.

Table 10. Important national bio-fuels promotion policies and objectives.

\begin{tabular}{|c|c|}
\hline Country & Objectives targeted by bio-fuels \\
\hline \multirow{2}{*}{ America } & $\begin{array}{l}\text { 1. President Bush announced twenty in ten in January } 2007 \text {, meaning gasoline to be consumed less by } \\
20 \% \text { in the next decade and replaced by bio-ethanol and other alternative fuels. }\end{array}$ \\
\hline & $\begin{array}{l}\text { 2. The Energy Independence and Security Act regulated in December } 2007 \text { that bio-ethanol should } \\
\text { account for } 4.6 \% \text { of transportation fuels in } 2012 \text { according to the Renewable Fuels Standard (RPS). }\end{array}$ \\
\hline \multirow{3}{*}{ Brazil } & 1. Ethanol was legally forced to be used as a fuel additive with a concentration of $20 \sim 25 \%$ in 1993. \\
\hline & 2. A provisional act for bio-fuels was promulgated in December 2004. \\
\hline & 3. B2 was enforced in 2008 and B5 would be enforced in 2013. \\
\hline \multirow{2}{*}{$\begin{array}{l}\text { European } \\
\text { Union }\end{array}$} & 1. Bio-fuels accounted for 4.25 and $5.00 \%$ of transportation fuels in 2008 and 2009 respectively. \\
\hline & $\begin{array}{l}\text { 2. An announcement was made in March } 2007 \text { that bio-fuels would account for } 5.75 \text { and } 10 \% \text { of } \\
\text { transportation fuels in } 2010 \text { and } 2020 \text {. }\end{array}$ \\
\hline China & Bio-fuels will account for 10 and $15 \%$ of transportation fuels in 2010 and 2020 respectively. \\
\hline Japan & Bio-fuels will account for $0.6,3$ and $10 \%$ of transportation fuels in 2010,2020 and 2030 individually. \\
\hline
\end{tabular}

Source of data: Taiwan Institute of Economic Research.

crude oil or those of WTI crude oil and Brent crude oil to corn, wheat and soybean are all mild and insignificant.

\section{Conclusion}

This research is based on the argument of the necessity of producing and developing bio-fuels and a relation between fluctuations of oil prices and grain prices is further explored. Thus, Chow Breakpoint Test and Quandt-Andrews unknown breakpoint test were used to examine whether the financial tsunami of 2008 resulted in any structural changes as far as WTI crude oil and Brent crude oil were concerned. The testing results were positive. Furthermore, as the closing prices of WTI crude oil and BRENT crude oil on July 14, 2008 were unprecedented high, July 15, 2008 was served as the breakpoint in this research. Thus, the research duration is divided into two sections, from January 1, 1991 to July 14, 2008 and from July 15, 2008 to July 15, 2010.

Paired variables were tested by VECM for causality and impulse responses between oil and grain prices. The causality testing results reveal variables of WTI crude oil, corn, wheat and soybean interacted mutually and so did those of Brent crude oil, corn, wheat and soybean during the period from January 1, 1991 to July 14,2008 . In other words, there was an explanatory power for each other. Nevertheless, the causality testing results in the duration from July 15, 2008 to July 15, 2010 are insignificant completely. As to the testing results of impulse 
responses, impulse responses of WTI crude oil and Brent crude oil to corn, wheat and soybean are significant during the period from January 1, 1991 to July 14, 2008 by fluctuations first and then keeping rising by periods afterwards. However, impulse responses in the duration from July 15, 2008 to July 15, 2010 are insignificant completely. In sum, this research verifies a relation existed between oil and grain prices during the period from January 1, 1991 to July 14, 2008 only. Their relationship in the duration from July 15, 2008 to July 15 , 2010 after the financial tsunami in 2008 is not that significant.

Skyrocketing oil prices are one of the major reasons for promoting bio-fuels and the bio-fuel policy-making started back to 2008 according to Table 10. As far as the testing results during the period from January 1, 1991 to July 14, 2008 are concerned, a relation between oil and grain prices exists indeed. Thus, the aspect that oil prices influenced production and prices of corn in America and the world proposed by Elobeid et al. (2007), and Runge et al. (2007) pointed that bio-fuel policies might cause rising grain prices held by Chen et al. (2010) are affirmed.

The relation between oil and grain prices during the period from July 15, 2008 to July 15, 2010 is insignificant indicating that the aspects of oil prices influencing grain prices and bio-fuels crowding out food provisions after structural changes in the financial tsunami of 2008 need to be reconsidered. Economic recession occurred in every country and the supply and demand for oil decreased in this financial storm. Take the United States as an example. The demand for bio-fuels also reduced (Figures 2 through 5 ) and the price of crude oil futures decreased from $\$ 140$ to 90 (Figure 6); however, grain prices still kept rising. In addition to well-known factors like climatic changes and an increase in global population, are there other factors worthy of exploration such as the production and marketing system of foodstuffs and development of Genetically Modified Organisms (GMO), etc. Do these factors impose impact upon fluctuations of grain prices that can't be neglected?

\section{REFERENCES}

Chen ST, Kuo HI, Chen CC (2010). Modeling the relationship between the oil price and global food prices. Appl. Energy, 87: 2517-2525.

Elobeid A, Tokgoz S, Hayes DJ, Babcock BA, Hart CE (2007). The long-run impact of corn-based ethanol on the grain, oilseed, and livestock sectors with implications for biotech crops. AgBioForum, 10(1): 11-8.

Granger CWJ (1988). Causality, cointegration and control. J. Econom. Control, 12: 551-559.

Hammoudeh S, Li H ( 2004). The impact of the Asian crisis on the behavior of US and international petroleum prices. Energy Econom., 26: 135-160.

Hansen BE (2001). The new economics of structure change: Dating breaks in U.S. labor productivity. J. Econom. Perspect., 15(4): 117128.

Johansen S (1988). Statistical analysis of cointegrating vectors. J. Econom. Dyn. Control, 12: 231-254.

Johansen S (1991). Estimation and hypothesis testing of cointegration vectors in Gaussian vector autoregressive models. Econometrica, 59: 1551-1580.

Johansen S (1992). A determination of co-integration rank in the presence of a linear trend? Oxford Bull. Econom. Stat., 54: 383-397.

Johansen S, Juselius K (1990). Maximum likelihood estimation and inference on ciontegration with applications to the demand for money. Oxford Bull. Econom. Stat., 52: 169-210.

Runge CF, Senauer B (2007). How biofuels could starve the poor. Foreign Aff., 86(3): 41-53.

Sims CA (1980). Macroeconomics and reality. Econometrica, 48: 1-48.

Sims CA (1988). Bayesian skepticism on unit root econometrics. J. Econom. Dyn. Control, 12: 463-474. 